\title{
PERANAN REGULASI EMOSI, KONTROL DIRI, PENERIMAAN DIRI TERHADAP PERILAKU AGRESIF SISWA SMP DI YOGYAKARTA
}

\author{
Ragil Adi Purnawan ${ }^{1}$, Nina Zulida Situmurang² \\ ${ }^{1}$ Jurusan Magister Psikologi Sains, Universitas Ahmad Dahlan Yogyakarta \\ Email: ragiladipurnawan94@gmail.com \\ ${ }^{2}$ Fakultas Psikologi, Universitas Ahmad Dahlan Yogyakarta \\ Email: nzsitumorang@gmail.com
}

Masuk : 21-01-2021, revisi: 17-04-2021, diterima untuk diterbitkan : 30-04-2021

\begin{abstract}
The aims of the study is to determine whether there is a role for emotional regulation, self-control, and self-acceptance of students' aggressive behavior at SMP X and Y in Yogyakarta. This study uses a quantitative approach and multiple linear regression analysis. This study uses four scales, namely a scale of emotional regulation, self-control, selfacceptance, and a scale of aggressive behavior. The subjects of this study were 140, consisting of 70 junior high school students at each school $X$ and $Y$ in Yogyakarta. The results of this study have a very significant relationship between the variables of emotional regulation, self-control, and self-acceptance of aggressive behavior in students of SMP $X$ and $Y$ in Yogyakarta. This is indicated by the obtained value of $F=13.924$ with $p=0.000(p<0.01)$. The $R$ square is 0.235 which if proxied $(0.235 \times 100 \%=23.5 \%)$ means that the contribution of emotional regulation, selfcontrol and self-acceptance to aggressive behavior is significant. $23.5 \%$, the remaining $76.5 \%$ is influenced by other factors not examined in this study. In partial correlation, it shows that the four proposed hypotheses are accepted. There is a very significant relationship between emotional regulation, self-control and self-acceptance of the aggressive behavior of students of SMP X and Y in Yogyakarta, so that the hypothesis can be accepted. The higher the emotional regulation, self-control and self-acceptance, the lower the aggressive behavior, conversely the lower the emotional regulation, self-control and self-acceptance, the higher the aggressive behavior.
\end{abstract}

Keywords: Emotional regulation, self-control, self-acceptance, aggressive behavior

ABSTRAK
Penelitian ini bertujuan untuk mengetahui apakah ada peranan regulasi emosi, Kontrol diri, dan penerimaan diri terhadap perilaku agresif Siswa di SMP X dan Y di Yogyakarta. Penelitian ini menggunakan pendekatan kuantitatif dan analisis regresi linier berganda. Penelitian ini menggunakan empat skala yaitu skala regulasi emosi, skala kontrol diri, skala penerimaan diri, dan skala perilaku agresif. Subjek penelitian ini adalah 140, terdiri dari 70 siswa SMP pada masing-masing sekolah X dan Y di Yogyakarta. Hasil dari penelitian ini terdapat hubungan yang sangat signifikan antara variabel regulasi emosi, kontrol diri, dan penerimaan diri terhadap perilaku agresif pada siswa SMP X dan Y di Yogyakarta. Hal tersebut ditunjukkan dengan diperoleh nilai $\mathrm{F}=13,924$ dengan $\mathrm{p}=0,000$ ( $\mathrm{p}<0,01$ ). $\mathrm{R}$ square sebesar 0,235 yang apabila diprosentasekan $(0,235 \times 100 \%=23,5 \%)$ artinya besar sumbangan regulasi emosi, kontrol diri, dan penerimaan diri terhadap perilaku agresif sebesar $23,5 \%$, sisanya 76,5\% dipengaruhi oleh faktor lain yang tidak diteliti dalam penelitian ini. Dalam korelasi secara parsial menunjukan ke empat hipotesis yang diajukan dinyatakan diterima. Terdapat hubungan yang sangat signifikan antara regulasi emosi, kontrol diri dan penerimaan diri terhadap perilaku agresif siswa SMP X dan Y di Yogyakarta, sehingga hipotesis dapat diterima. Semakin tinggi regulasi emosi, kontrol diri dan penerimaan diri, maka semakin rendah perilaku agresif, sebaliknya semakin rendah regulasi emosi, kontrol diri dan penerimaan diri, maka semakin tinggi perilaku agresif.

Kata Kunci: Regulasi emosi, kontrol diri, penerimaan diri, perilaku agresif

\section{PENDAHULUAN}

\section{Latar Belakang}

Hampir setiap hari media massa menyajikan berita-berita tentang kenakalan remaja, terutama di kota-kota besar. Perbuatan-perbuatan tersebut tidak hanya merugikan pelakunya tetapi juga merugikan orang lain baik harta maupun jiwa, serta meresahkan mengancam ketentraman rakyat. Melihat fenomena kasus agresif di media massa (TribunJatim.com, 2019) di Gresik terdapat kasus tentang perilaku agresif siswa terhadap guru, siswa melakukan tindakan penganiayaan terhadap gurunya sendiri. 
Perilaku agresif yang dibiarkan begitu saja, pada saat remaja nantinya akan menjadi juvenile delinquency yakni perilaku kenakalan remaja. Perilaku agresif dari sejak anak berusia dini berpengaruh pada perkembangan anak selanjutnya (Kim et al., 2011). Barnow et al. (2005) berpendapat dampak negatif dari agresif, salah satunya kenakalan remaja. Johnson et al. (2000) juga berpendapat dampak negatif dari perilaku agresif antara lain mendorong penyalahgunaan zat adiktif dan kenakalan remaja lainnya. Penelitian Milaniak \& Widom (2015) menunjukkan bahwa perilaku agresif mendorong remaja melakukan tindakan melukai orang lain yang bahkan bisa membuat orang lain tersakiti baik secara psikis dan fisik.

Menurut Buss dan Perry (1992) menyatakan perilaku agresif sebagai perilaku yang niatnya untuk menyakiti orang lain baik secara fisik maupun secara psikologis. Buss dan Perry (1992) juga menyatakan, terdapat empat aspek perilaku agresif yang didasari dari tiga dimensi dasar yaitu motorik, afektif, dan kognitif. Empat aspek perilaku agresi menurut Buss dan Perry yaitu sebagai berikut: (a) physical aggression meliputi memukul, menendang, mendorong; (b) verbal aggression meliputi berteriak, mengejek, berkata kotor, mencela; (c) anger meliputi marah, kesal, emosi, jengkel; dan (d) hostility meliputi cemburu, sedih, sensitif, serta iri.

Perilaku agresif oleh para siswa anak laki-laki yaitu seperti mengucapkan kalimat-kalimat yang tidak pantas dan tidak baik untuk diucapkan, dan terlibat dalam kegiatan yang merusak, memusnahkan barang-barang temannya sendiri, sedangkan perilaku agresif pada perempuan yang jarang diamati dalam kalimat-kalimat yang tidak pantas untuk diucapkan. Terjadi pertarungan fisik laki-laki yang sering dilakukan, yang disebabkan dari pergaulan lingkungan teman bermainnya (Fatimah \& Malik, 2015; Greene 2005). Hal itu sejalan dengan Kaur dan Niwa (2017) yang menjelaskan bahwa dampak negatif dari tindakan perilaku agresif yaitu berupa melukai dirinya sendiri maupun orang lain.

Penelitian Garofalo dan Velotti (2017) tentang emosi negatif dan perilaku agresif pada pelaku kekerasan menjelaskan bahwa emosi yang negatif akan membuat remaja mudah melakukan agresi fisik, sehingga remaja yang mempunyai emosi yang negatif cenderung melakukan tindakan agresi fisik terhadap temannya. Kebalikannya jika remaja bisa mengontrol emosinya akan cenderung tidak melakukan tindakan agresi fisik.

Regulasi emosi menurut Gross dan Thompson (2007) adalah strategi yang dilakukan oleh individu secara sadar maupun tidak sadar untuk mempertahankan perilaku, memperkuat, mengurangi emosi yaitu dengan untuk mempertahankan keinginannya dalam berperilaku yang bertentangan dengan norma sosial. Hal ini didukung oleh hasil penelitian Meldrum et al. (2016) yang menyatakan anak dapat mengontrol dirinya dari pola asuh orang tuanya, jika orang tuanya dapat memberikan pengalaman emosi dan perilaku yang dimiliki oleh individu. Gunarsa dan Gunarsa (2000) kontrol diri adalah kemampuan individu contoh perilaku yang baik terhadap anaknya, maka anak akan dapat mengontrol dirinya dengan baik. Penelitian Li et al. (2019) juga menunjukkan bahwa individu yang memiliki pengendalian diri yang rendah lebih mungkin untuk terlibat dalam perilaku agresif, tindakan kriminal dan menyimpang dibandingkan dengan mereka yang memiliki tingkat kontrol diri yang tinggi, Penjelasan lain menunjukkan gender dikaitkan dengan kecenderungan melakukan perilaku agresif, sehingga laki-laki memiliki tingkat agresif yang tinggi untuk melakukan kekerasan (Keatley et al., 2017).

Selain kontrol diri ditemukan faktor lain yang menunjukkan perilaku agresif yaitu tentang penerimaan diri. Setiap individu yang memiliki harga diri yang tinggi maka individu tersebut akan memiliki penerimaan diri yang rendah, sedangkan individu yang memiliki harga diri yang rendah 
akan memiliki penerimaan diri yang lebih tinggi (Cristian Vasile, 2012). Penerimaan diri mempunyai hubungan realistik antara keadaan dirinya dengan keinginannya, tanpa merasa terbebani serta menerima keterbatasan diri secara realistik tanpa merasa diri tercela (Hurlock, 2003).

Berdasarkan permasalahan di atas, dan mengamati fenomena yang terjadi, maka peneliti tertarik untuk melakukan penelitian mengenai peranan regulasi emosi, kontrol diri dan penerimaan diri terhadap perilaku agresif. Tujuan dari penelitian ini adalah untuk mengetahui peranan regulasi emosi, kontrol diri, dan penerimaan diri terhadap perilaku agresif siswa SMP di Yogyakarta.

\section{Rumusan Masalah}

Berdasarkan latar belakang masalah maka perumusan masalah dalam penelitian adalah "Apakah ada peranan regulasi emosi, kontrol diri, dan penerimaan diri terhadap perilaku agresif siswa SMP di Yogyakarta?"

\section{METODE PENELITIAN}

\section{Partisipan penelitian}

Partisipan penelitian ini merupakan peserta didik SMP X dan Y di Yogyakarta yang berstatus aktif di sekolah. Adapun partisipan dalam penelitian ini adalah peserta didik yang cenderung mempunyai perilaku agresif yang dimana masing-masing sekolah berjumlah 70 peserta didik yang dibantu oleh guru BK untuk mendapatkan data peserta didik berperilaku agresif, jadi total partisipan dalam penelitian ini terdiri dari 140 peserta didik SMP X dan Y di Yogyakarta.

\section{Pengumpulan data}

Metode yang digunakan untuk mengumpulkan data yang dibutuhkan dalam penelitian ini adalah metode pengukuran skala untuk pengukuran variabel bebas dan variabel tergantungnya. Peneliti menyusun butir-butir yang mengungkap masing-masing indikator variabel. Penyusunan skala berdasarkan pembagian butir yang terdiri dari butir favorable dan unfavorable. butir favorable adalah butir yang isinya mendukung, memihak, atau menunjukkan ciri adanya atribut yang diukur, sedangkan butir unfavorable adalah butir yang isinya tidak mendukung atau tidak menggambarkan ciri atribut yang diukur (Azwar, 2013).

Metode pengumpulan data dalam penelitian ini adalah dengan menggunakan, (a) penyusunan skala perilaku agresif berdasarkan teori Buss dan Perry (1992) menjelaskan 4 aspek perilaku agresif, sehingga peneliti membuat skala perilaku agresif berjumlah 40 butir favorable dan unfavorable; (b) skala regulasi emosi disusun berdasarkan 4 aspek regulasi emosi yang dikemukakan oleh Gross dan Thompson (2007), sehingga peneliti membuat skala regulasi emosi berjumlah 48 butir favorable dan unfavorable; (c) penyusunan skala kontrol diri berdasarkan teori Averill (1973) menjelaskan 3 aspek kontrol diri, sehingga peneliti membuat skala kontrol diri berjumlah 36 butir favorable dan unfavorable; dan (d) skala penerimaan diri disusun berdasarkan 10 aspek yang membentuk penerimaan diri yang dikemukakan oleh Jersild (1978), sehingga peneliti membuat skala penerimaan diri berjumlah 60 butir favorable dan unfavourable. Metode yang digunakan untuk menguji hipotesis penelitian adalah teknik analisis regresi linier berganda, yaitu empat variabel yang masing masing datanya berwujud skor. Data yang telah dikumpulkan melalui empat skala dilakukan uji asumsi terlebih dahulu sebelum dilakukan uji hipotesis, yaitu uji normalitas, linieritas dan multikolinieritas. Seluruh analisis data menggunakan program komputer, yaitu Statistical Packages for Social Sciences (SPSS) versi 20 untuk windows. 


\section{HASIL DAN PEMBAHASAN}

Penelitian ini dilakukan pada seluruh peserta didik di SMP X dan Y di Yogyakarta yang berjumlah 140 siswa yang mempunyai kecenderungan perilaku agresif. Peneliti meminta bantuan dari guru BK yang bertugas untuk memilih kelas atau peserta didik yang memiliki kecenderungan perilaku agresif.

Tabel 1.

\begin{tabular}{|c|c|c|}
\hline Jenis Kelamin & Frekuensi & Persentase (\%) \\
\hline Laki-laki & 120 & 85,71 \\
\hline Perempuan & 20 & 14,29 \\
\hline Total & 140 & 100 \\
\hline
\end{tabular}

Berdasarkan tabel diatas dapat diketahui bahwa dari 140 subjek. Mayoritas subjek berjenis kelamin laki-laki yaitu 120 siswa $(85,71 \%)$, subjek yang berjenis kelamin perempuan ada sebanyak 20 siswa $(14,29 \%)$.

Tabel 2.

Karakteristik Subjek Berdasarkan Usia

\begin{tabular}{ccc}
\hline Umur (tahun) & Frekuensi & Persentase (\%) \\
\hline 13 & 20 & 14,29 \\
\hline 14 & 50 & 35,71 \\
\hline 15 & 70 & 50 \\
\hline Total & 140 & 100 \\
\hline
\end{tabular}

Berdasarkan tabel diatas dapat diketahui bahwa dari 140 subjek, mayoritas berusia 15 tahun yaitu 70 siswa (50\%), subjek terbanyak kedua berusia 14 tahun yaitu 50 siswa (35,71\%), dan subjek termuda berusia 13 tahun yakni sebanyak 20 siswa (14.29\%).

Berdasarkan data tersebut, guru BK merekrut sebanyak 140 siswa berperilaku agresif. Siswa tersebut terdiri dari 120 siswa laki-laki dan 20 siswa perempuan yang memiliki perilaku agresif. Hasil analisis data yang telah dilakukan berdasarkan profil dari responden menunjukkan bahwa siswa laki-laki mayoritas melakukan tindakan perilaku agresif dibandingkan dengan siswa perempuan. Sedangkan dilihat dari usia 13 tahun sampai 15 tahun, mayoritas yang melakukan tindakan perilaku agresif pada usia 15 tahun sebanyak 70 siswa.

Untuk menguji hipotesis mayor digunakan analisis regresi. Berdasarkan hasil analisis data diketahui bahwa besarnya pengaruh antara variabel regulasi emosi, kontrol diri, dan penerimaan diri terhadap perilaku agresif diperoleh skor $F=13,924$ dengan nilai $p=0,000(p<0,01)$ sehingga hipotesis mayor dapat diterima. Hal ini menunjukan bahwa terdapat hubungan yang sangat signifikan antara variabel regulasi emosi, kontrol diri, dan penerimaan diri terhadap perilaku agresif pada siswa SMP X dan Y di Yogyakarta. Hasil analisis bisa dilihat pada tabel 3.

Tabel 3.

Hasil Uji Analisis Secara Simultan

\begin{tabular}{ccccc}
\hline Hipotesis & $\mathbf{F}$ & $\mathbf{R}^{2}$ & Sig (p) & Keterangan \\
\hline $\begin{array}{c}\mathrm{X}_{1}, \mathrm{X}_{2} \text {, dan } \mathrm{X}_{3} \\
\text { dengan } \mathrm{Y}\end{array}$ & 13,924 & 0,235 & 0,000 & $\begin{array}{c}\text { Sangat } \\
\text { Signifikan }\end{array}$ \\
\hline
\end{tabular}


Hasil analisis data secara parsial dapat dilihat pada tabel 4 di bawah ini:

Tabel 4.

Hasil Analisis Secara Persial

\begin{tabular}{lcc}
\hline \multicolumn{1}{c}{ Variabel } & Beta & Signifikansi \\
\hline Regulasi emosi dengan perilaku agresif & $-0,210$ & 0,009 \\
\hline Kontrol diri dengan perilaku agresif & $-0,244$ & 0,003 \\
\hline Penerimaan diri dengan perilaku agresif & $-0,361$ & 0,000 \\
\hline
\end{tabular}

Data yang diperoleh dari hasil analisis data diketahui bahwa besarnya peranan variabel regulasi emosi dengan perilaku agresif diperoleh skor beta $=-0,210$ dengan nilai $p=0,009(p<0,01)$ sehingga hipotesis minor pertama dapat diterima. Hal ini menunjukkan bahwa terdapat peranan yang sangat signifikan antara regulasi emosi dengan perilaku agresif.

Peranan kontrol diri dengan perilaku agresif diperoleh skor beta $=-0,244$ dengan nilai $\mathrm{p}=0,003$ $(\mathrm{p}<0,01)$ sehingga hipotesis minor kedua diterima. Hal tersebut menunjukkan ada peranan yang sangat signifikan antara kontrol diri dengan perilaku agresif.

Peranan penerimaan diri dengan perilaku agresif diperoleh beta $=-0,361$ dengan nilai $p=0,000$ $(\mathrm{p}<0,01)$ sehingga hipotesis minor ketiga dapat diterima. Hal ini menunjukan ada peranan yang sangat signifikan antara penerimaan diri dengan perilaku agresif.

Berdasarkan uji statistik di atas, hipotesis minor yang diajukan teruji kebenarannya. Hal ini menunjukkan ada peranan yang sangat signifikan antara regulasi emosi, kontrol diri dan penerimaan diri terhadap perilaku agresif pada siswa SMP X dan Y di Yogyakarta, yang berarti semakin tinggi regulasi emosi, kontrol diri dan penerimaan diri akan semakin rendah juga perilaku agresif nya dan begitu pula sebaliknya, semakin rendah regulasi emosi, kontrol diri dan penerimaan diri maka semakin tinggi juga perilaku agresif. Sumbangan masing-masing Variabel bebas terhadap variabel tergantung. Rumus Sumbangan Efektif (SE):

$\mathrm{SE}=$ Beta $\mathrm{x}$ zero order $\mathrm{x} 100 \%$

Beta $\quad=$ nilai koefisien standar

Zero order $(\mathrm{r}) \quad=$ nilai korelasi

Tabel 5.

Nilai Sumbangan Variabel Bebas Terhadap Variabel Tergantung

\begin{tabular}{|c|c|c|c|}
\hline Variabel & Beta & Zero order & SE \\
\hline Regulasi emosi terhadap Perilaku agresif & 0,210 & $-0,270$ & $5,67 \%$ \\
\hline Kontrol diri terhadap Perilaku agresif & 0,244 & $-0,265$ & $6,47 \%$ \\
\hline Penerimaan diri terhadap Perilaku agresif & 0,361 & $-0,315$ & $11,37 \%$ \\
\hline
\end{tabular}

Berdasarkan hasil analisis diatas, diketahui bahwa sumbangan efektif (SE) variabel regulasi emosi terhadap perilaku agresif sebesar 5,67\%. Sumbangan pada variabel kontrol diri terhadap perilaku agresif sebesar $6,47 \%$. Sedangkan sumbangan pada variabel penerimaan diri terhadap perilaku agresif sebesar $11,37 \%$. Artinya variabel penerimaan diri memiliki sumbangan efektif lebih besar dibandingkan variabel kontrol diri dan variabel regulasi emosi terhadap perilaku agresif. Sumbangan total regulasi emosi, kontrol diri dan penerimaan diri terhadap perilaku agresif sebesar $23,5 \%$, sedangkan sisanya $76,5 \%$ dipengaruhi oleh variabel lain yang tidak diteliti dalam penelitian ini. 
Hasil penelitian menunjukkan adanya peranan antara variabel regulasi emosi, kontrol diri dan penerimaan diri terhadap perilaku agresif. Hal tersebut ditunjukkan dengan diperoleh nilai $\mathrm{F}=$ 13,924 dengan $\mathrm{p}=0,000(\mathrm{p}<0,01)$. Artinya terdapat peranan yang sangat signifikan antara regulasi emosi, kontrol diri dan penerimaan diri terhadap perilaku agresif pada siswa SMP X dan Y di Yogyakarta, sehingga hipotesis dapat diterima.

Hasil tersebut sesuai dengan penelitian yang dilakukan oleh Thohar (2017) yang diperoleh bahwa ada regulasi emosi peranan secara signifikan terhadap perilaku agresif pada remaja. Regulasi emosi yang baik dapat membantu seseorang dalam mengontrol emosinya. Remaja dalam kesehariannya cenderung sulit untuk mengontrol emosinya karena memiliki emosi yang bergejolak di usianya.

Regulasi emosi menurut Thohar (2017) dapat dijadikan sebagai kemampuan untuk merespon proses ekstrinsik dan intrinsik untuk membantu memonitor, mengevaluasi, dan memodifikasi reaksi emosi yang yang intens untuk mencapai suatu tujuan. Hal tersebut berarti apabila individu mampu mengelola emosi dengan baik, maka individu diharapkan mampu memiliki daya tahan dalam menghadapi suatu masalah dan akan berperilaku positif sehingga meminimalisir munculnya perilaku agresif.

Selanjutnya penelitian yang dilakukan oleh Sulton (2011) diperoleh hasil bahwa perilaku agresif dipengaruhi oleh kontrol diri. Perilaku agresif muncul karena beberapa sebab, pertama yaitu karena bawaan biologis sehingga memunculkan tingkah laku yang agresif. Kedua, disebabkan oleh kondisi lingkungan yang membuat individu mempelajari berbagai macam tingkah laku yang muncul di sekitarnya.

Untuk meminimalisir munculnya perilaku agresif pada diri seseorang, diperlukan kemampuan yang baik dalam mengontrol diri. Saat kemampuan kontrol diri baik, maka seseorang dapat mengendalikan perilakunya sehingga ketika mengambil keputusan akan lebih efektif dan saat memilih tindakan maka akan dapat menghindari akibat buruk yang tidak diinginkan.

Sumbangan efektif yang didapat dapat dari hasil penelitian menunjukkan variabel regulasi emosi, kontrol diri dan penerimaan diri memberikan sumbangan efektif sebesar 23,5\% terhadap perilaku agresif dengan hasil analisis R square 0,235 . Hal ini menunjukkan adanya faktor lain di luar ketiga variabel bebas yang diteliti sebesar 76,5\% yang dapat mempengaruhi perilaku agresif. Buss dan Perry (1992) menyatakan faktor lain yang dapat mempengaruhi perilaku agresif yaitu sifat, jenis kelamin, keyakinan, sikap, nilai yang dianut, dan tujuan jangka panjang.

Selanjutnya variabel regulasi emosi memberikan sumbangan sebesar 5,67\% terhadap perilaku agresif. Variabel kontrol diri memberikan sumbangan terhadap perilaku agresif sebesar 6,47\% . Terakhir variabel penerimaan diri terhadap perilaku agresif memberikan sumbangan efektif $11,37 \%$ terhadap perilaku agresif.

Selanjutnya subjek penelitian pada variabel regulasi emosi, kontrol diri, penerimaan diri dan perilaku agresif termasuk dalam kategori sedang, artinya perilaku subjek penelitian menunjukan perilaku yang masih berada dalam batasan-batasan normatif pada umumnya. Hal ini sejalan dengan data yang ditemukan dilapangan yaitu pada saat wawancara siswa SMP. Hasil wawancara dengan siswa menjelaskan bahwa, di sekolah sudah diajarkan untuk menjalani pola kehidupan yang teratur dengan mengikuti aturan dan norma yang berlaku di sekolah. Aturan yang ada dan diterapkan pada siswa di sekolah secara langsung maupun tidak langsung membuat siswa mampu 
meningkatkan regulasi emosi, kontrol diri, dan penerimaan dirinya. Sehingga hal tersebut dapat mengurangi munculnya perilaku agresif pada diri para siswa.

\section{KESIMPULAN DAN SARAN}

Berdasarkan penelitian ini, peneliti dapat menyimpulkan beberapa penjelasan sebagai berikut: (a) ada peranan yang sangat signifikan antara regulasi emosi, kontrol diri dan penerimaan diri terhadap perilaku agresif siswa SMP X dan Y di Yogyakarta. Semakin tinggi regulasi emosi, kontrol diri dan penerimaan diri maka semakin rendah perilaku agresif, sebaliknya semakin rendah regulasi emosi, kontrol diri, dan penerimaan diri maka semakin tinggi perilaku agresif; (b) terdapat peranan negatif yang sangat signifikan antara regulasi emosi terhadap perilaku agresif siswa SMP X dan Y di Yogyakarta. Semakin tinggi regulasi emosi maka semakin rendah perilaku agresif, sebaliknya semakin rendah regulasi emosi maka semakin tinggi perilaku agresif; (c) terdapat peranan negatif yang sangat signifikan antara kontrol diri terhadap perilaku agresif siswa SMP X dan Y di Yogyakarta. Semakin tinggi kontrol diri maka semakin rendah perilaku agresif, sebaliknya semakin rendah kontrol diri maka semakin tinggi perilaku agresif; dan (d) ada peranan negatif yang sangat signifikan antara penerimaan diri terhadap perilaku agresif siswa SMP X dan Y di Yogyakarta. Semakin tinggi penerimaan diri maka semakin rendah perilaku agresif, sebaliknya semakin rendah penerimaan diri maka semakin tinggi perilaku agresif. Di dalam studi ini ketiga variabel bebas secara keseluruhan memiliki pengaruh sebesar 23,5\% saja terhadap perilaku agresif. Terdapat $76,5 \%$ sumbangan dari variabel lain yang belum diketahui. Oleh karena itu, kepada para peneliti selanjutnya yang berminat untuk melakukan penelitian dengan tema perilaku agresif dapat menggali variabel lain nya. Dengan ditemukannya variabel lain yang juga berkontribusi untuk mengurangi perilaku agresif, maka intervensi dapat dilakukan dengan lebih komprehensif. Saran untuk siswa selama masa sekolah siswa diharapkan bukan hanya memiliki kemampuan akademik. Namun juga harus memiliki soft skill antara lain regulasi emosi, kontrol diri, penerimaan diri yang baik, agar mampu meminimalisir munculnya perilaku agresif pada dirinya.

\section{Ucapan Terima Kasih (Acknowledgement)}

Ucapan terimakasih dalam penelitian ini penulis tujukan kepada fakultas psikologi program studi magister psikologi sains dan sekolah SMP X dan Y di Yogyakarta.

\section{REFERENSI}

Azwar, S. (2013). Metode penelitian. Pustaka Belajar.

Averill, J. R. (1973). Personal control over aversive stimuli and its relationship to stress. Psychological Bulletin, 80(4), 286-303. https://doi/10.1037/h0034845.

Barnow, S., Lucht, M., \& Freyberger, H. J. (2005). Correlates of aggressive and delinquent conduct problems in adolescence. Aggressive Behavior, 31(1), 24-39. https://doi/10.1002/ab.20033.

Buss, A. H., \& Perry, M. (1992). The aggression questionnaire. Journal of Personality and Social Psychology, 63(3), 452-459. https://doi.org/10.1037/0022-3514.63.3.452

Cristian vasile. (2012). An evaluation of self-acceptance in adults. Procedia - Social and Behavioral Sciences, 78 (2013), 605 - 609. https:/doi/10.1016/j.sbspro.2013.04.360

Fatima, S. \& Malik, S. K. (2015). Causes of students' aggressive behavior at secondary school level. Journal of Literature, Languages and Linguistics, 11, 2422-8435.

Garofalo, C., \& Velotti, P. (2017). Negative emotionality and aggression in violent offenders: The moderating role of emotion dysregulation. Journal of Criminal Justice, 51, 916. https://doi/10.1016/j. jcrimjus.2017.05.015 
Greene, M. B. (2005). Reducing violence and aggression in schools. Trauma, Violence, \& Abuse, 6(3), 236-253. https://doi/10.1177/ 1524838005277406

Gross, J. J., \& Thompson, R. A. (2007). Emotion regulation. handbook of emotion regulation. Guilford Publication.

Gunarsa, S. D., \& Gunarsa, Y. S. D. (2000). Psikologi praktis: anak, remaja, dan keluarga. PT. BPK Gunung Mulia.

Hurlock, E. B. (2003). Psikologi perkembangan ( $5^{\text {th }}$ Ed.). Erlangga.

Jersild, A. T. (1978). The psychology of adolescence. McMillan Company.

Johnson. J. G.,Cohen. P, Smailes. E, Kasen. S, Oldham. J. M, Skodol. A.E., \& Brook J. S. (2000). Adolescent personality disorders associated with violence and criminal behavior during adolescence and early adulthood. Am $J$ Psychiatr, 157, 1406-1412. http://doi.org/10.1176/appi.ajp.157.9.1406

Keatley, D. A., Allom, V., \& Mullan, B. (2017). The effects of implicit and explicit self-control on self-reported aggression. Personality and Individual Differences, 107, 154-158. https://doi/10.1016/j.paid. 2016.-11.046

Kaur, D \& Niwa R. (2017). Aggressive behaviour of secondary school students in relation to school environment. International Journal of Advanced Research (IJAR), 5(5), 801-809. https://doi/10.21474/ ijar01/4182

Kim, S., Orpinas, P., Kamphaus, R., \& Kelder, S. H. (2011). A multiple risk factors model of the development of aggression among early adolescents from urban disadvantaged neighborhoods. School Psychology Quarterly, 26(3), 215-230. https://doi.org/10.1037/a0024116

Li, J.-B., Dou, K., Situ, Q.-M., Salcuni, S., Wang, Y.-J., \& Friese, M. (2019). Anger rumination partly accounts for the association between trait self-control and aggression. Journal of Research in Personality. https://doi/10.1016/j.jrp.2019.06.011

Meldrum, R. C., Verhoeven, M., Junger, M., van Aken, M. A. G., \& Deković, M. (2016). Parental self-control and the development of male aggression in early childhood: A longitudinal test of self-control theory. International Journal of Offender Therapy and Comparative Criminology, 62(4), 935-957. https://doi/10.1177/0306624x16 662921.

Milaniak, I., \& Widom, C. S. (2015). Does child abuse and neglect increase risk for perpetration of violence inside and outside the home. Psychology of Violence, 5(3), 246-255. https://doi/10.1037/a0037956.

Sulton, M. (2011). Hubungan antara kontrol diri dengan perilaku agresif pada supporter remaja. IAIN Ampel, 1(1), 1-15.

Thohar, S. F. (2017). Regulasi emosi sebagai prediktor perilaku agresif remaja warga binaan LPKA. Psikoislamika, 15(1), 29-34. https://doi.org/10.18860/psi.v15i1.6660

TribunJatim.com. (2019, Februari 11). Kasus siswa aniaya guru di Gresik, psikolog: Bila menemui siswa agresif, guru diimbau jangan diam. https://jatim.tribunnews.com/2019/02/11/kasussiswa-aniaya-guru-di-gresik-psikolog-bila-menemui-siswa-agresif-guru-diimbau-jangandiam 